The publication of this volume at a time when new anti-pollution legislation is just coming into operation is most opportune, and all who are concerned with pollution prevention will find it an invaluable work of reference. J. MoNicholas

\section{Principles of Organic Chemistry}

By T. A. Geissman. Second edition. (A Series of Chemistry Books.) Pp. $x+854$. (San Franciseo and London: W. H. Freeman and Company, 1962.) $35 s$.

THE second edition of Geissman has appeared about three years after the first; it is both larger and cheaper than the latter. The increase in size is due partly to a larger and clearer type-face, more headings and a better lay-out, and partly to the inclusion of three new chapters and three appendixes.

The main content and presentation of material have not been changed appreciably. Prof. Geissman has again set out to develop the principles of organic chemistry, and has chosen factual material largely to illustrate these principles. Some sections of the original book have been shortened or deleted, others have been expanded, rewritten, or added. The first new chapter, early in the book, is an introduction to the main classes of organic compounds in terms of important functional groups. The second is $a_{\mathbf{a}}$ discussion of polymerization from the point of view of the application of the general principles of bond formation to polymer synthesis. The third new chapter describes the structural determination of some complex natural products by degradation and by synthesis; this chapter illustrates the application of some of the principles discussed earlier in the book, but does not include an account of the use of spectroscopic and other physical techniques. The appendixes are composed of a list of reaction types with references to the text, a list of fifty preparations from Organic Syntheses, and finally a key to the questions on each chapter.

It should be noted that the clear drawings of molecular models in the new edition are a great improvement on the rather impressionistic diagrams in the original book. In all, the changes and additions have turned an already good book into one of the best introductory texts of organic chemistry available.

C. B. REesE

\section{Organic Synthesis}

An Annual Publication of Satisfactory Methods for the Preparation of Organic Chemicals, Vol. 41. Editor-inChief: John D. Roberts. Pp. ix +118. (New York and London: John Wiley and Sons, Inc., 1961.) $30 s$.

A $\mathbf{S}$ indicated in an editorial note, this series came into being at the end of the First World War through the shortage of supplies of organic chemicals from abroad at that time. Because of its unfailing care, precision, and judicious choice, the series became an outstanding success from the very beginning. Conditions have now changed, and an amazing variety of organic compounds may be obtained commercially. The present-day emphasis of the series is attached to illustrating new and general types of organic reactions and compounds; so much so, that more than a third of the reactions and compounds of the present volume have come to light only during the preceding five years.

Originally, directions were aimed at the preparation of substantial quantities of the selected compounds. However, the newer methods of organic chemistry call for decreasing quantities for use in investigations, and this feature is reflected in some of the items. Notably, attention is directed to the smallest-scale synthesis of the whole series: this appears in the volume under notice, and concerns the preparation of 0.0005 mole of cholestanyl methyl ether by a general procedure using diazomethane and fluoboric acid. Incidentally, the twenty-nine preparations described here include a new unpublished method for diazomethane; and among substances of particular interest are norcarane and ruthenocene, the latter being a stable $\pi$-bonded organometallic compound which displays substitution reactions resembling those of ferrocene. JoHN ReaD

\section{European Brewery Convention}

Proceedings of the Congress, Vienna, 1961. Pp. xi +460 . (Amsterdam: Elsevier Publishing Company, 1961.) 708.

THE biennial congresses of the European Brewery Convention attract a greater concentration of those concerned with scientific aspects of brewing than any other meetings. This volume, consisting of 45 communications of which all but a few describe original experimental work, emphasizes both the breadth of the field involved and the great usefulness of the meetings themselves. The papers, in English, French or German with trilingual summaries, came not only from industry but also from universities and other centres of research in some fifteen countries. The topics range from enzymatic aspects of fermentation and malting to yeast genetics, from fractionating barley proteins to the origin and nature of the flavonoid compounds in brewing materials and from the structural chemistry of hop resins to the polysaccharides remaining in highly fermented beers. The techniques used likewise embrace a bewilderingly wide field including micro. enzymatic methods and the various forms of chromatography. These investigations would be less valuable if not mostly directed to meet industrial problems but, even so, the several contributions of a more obviously applied nature reveal a remarkable spirit of change in the fermentation industries. For example, the deliberate control of malting loss without adverse effect on malt quality, further specific malting improvements and continuous brewing generally are all advances based on science and which to those on the production side must have seemed remote and indeed unlikely even as recently as 5-7 years ago. Though inevitably uneven in scientific quality, this book has many lessons for scientists everywhere irrespective of industrial interests and one overriding lesson as to the impact which science can have even on those industries which are sometimes regarded as unchanging and unchangeable.

A. H. CoOK

\section{Report on the Lands of the Arid Region of the United States}

With a more detailed account of the Lands of Utah. By John Wesley Powell, edited by Prof. Wallace Stegner. The John Harvard Library. (Cambridge, Mass.: The Belknap Press of Harvard University Press and London: Oxford University Press, 1962.) 40s.

7 HE development of an intensive arid zone programme by Unesco has directed much attention on the problems of the world's dry regions and their development. Those to whom the name John Wesley Powell does not stir a chord of memory might be excus this book the latest on developments in the United States. It is in fact one of the Harvard reprints of classics, and the word 'classic' is justly applied to this report made in 1878 to the Secretary of the Interior by the Director of the United States Geographical and Geological Survey of the Rocky Mountain Region.

A one-armed Civil War veteran, Major Powell, became briefly a national hero from his exploration of the Colorado Canyon in 1869. He foresaw that to try and impose on the arid west the land laws, land management and systems of farming successful in the well-watered lands of the east could only bring disaster. He saw that to settle homesteadors on 160-acre square plots was sheer nonsense, and he said so in forthright terms that rendered his report fiercely controversial. Although Powell predicted with uncanny accuracy the droughts, floods, crop failures. communal quarrels and individual tragedies which would result, and continued to campaign accordingly antil his 